\title{
Top-down effects on intertidal mussel populations: assessing two predator guilds in a South African marine protected area
}

\author{
Jeremiah G. Plass-Johnson*, Christopher D. McQuaid, Francesca Porri \\ Coastal Research Group, Zoology and Entomology Department, Rhodes University, P. O. Box 94, 6140 Grahamstown, \\ South Africa
}

\begin{abstract}
Mussels are important ecological engineers and occupiers of intertidal space in many parts of the world, where their populations are shaped by top-down regulation through predation on adults. In South Africa, adult predation is believed to be low, with mussel populations limited by competition or bottom-up supply of recruits. We tested the hypothesis that predation shapes these populations at the recruit rather than the adult stage by measuring predation on recruits at 2 rocky shores $100 \mathrm{~m}$ apart in a marine reserve, with no-take regulations. To explore the role of different guilds of predators, we used 7 treatments (fences, roofs, cages plus appropriate controls) to discriminate between the effects of benthic and pelagic predators. Factorial ANOVA showed that both types of predation had strong effects. Juvenile mussels were quickly removed in treatments with a roof (which excluded pelagic predators), a fence (which excluded benthic predators), and unprotected controls exposed to all predators. Treatments that excluded only one guild of predators were significantly different from the full cage, but not different from each other or the fully exposed control treatment. Thus, benthic and pelagic predators had similar effects that were not significantly different, suggesting that interference may occur between predator guilds. Under experimental conditions, the combined pressure of benthic and pelagic predators resulted in high mortality that may have topdown effects on mussel populations through recruit rather than adult predation.
\end{abstract}

KEY WORDS: Intertidal $\cdot$ Mussels $\cdot$ Predator exclusion experiment $\cdot$ South Africa $\cdot$ Marine protected areas $\cdot$ MPA $\cdot$ Top-down regulation

\section{INTRODUCTION}

While abiotic conditions set a framework of those species that are capable of living in a particular place (McQuaid \& Branch 1984), the recent upsurge in biological invasions, particularly in the marine environment (Ruiz et al. 1997, Rilov \& Crooks 2009), has highlighted how critical it is that organisms are able to reach and colonise a habitat. Given a suite of species that can reach and survive in a particular marine benthic habitat, the realised community is often strongly shaped by biological interactions including competition for space (Griffiths \& Hockey 1987), facilitation (Bruno et al. 2003), and predation (Paine 1969). The balance among these various forces remains unclear, however (e.g. Stokstad 2009), and it seems likely that it will differ from place to place.

In temperate littoral systems, mussels are ubiquitous habitat-forming animals (Gosling 1992), and in many parts of the world they risk predation below a given tidal height, but find refuge higher on the shore (Kitching et al. 1959, Connell 1972, Robles et al. 2009). Thus, the physical limitations of the predator can set the lower boundary for spatial refuge (Kitching et al. 1959, Muntz et al. 1965, Paine 1974, 1977, Saier 2001). Predation is considered to be important to mussel communities, not only because it is a primary mechanism that accounts for patterns in their distribution and abun- 
dance, but also because the coexistence dynamics between predator and prey (Holt 1977, Power 1992) help to maintain local diversity; for example by preventing habitat monopolisation (Petraitis et al. 1989, Robles \& Desharnais 2002). Processes, including predation, that maintain spatial patterns in mussel populations largely work on early life stages, and occasionally large individuals can be found beyond the general lower limits of distribution. Refuge in size can occur when mussels are able to reach a size beyond the feeding capabilities of the predator. This may occur when predator densities are low (Paine 1974) due to environmental stressors or stochastic population fluctuations. Escape from predation can also occur in topographically complex habitats where the settlement site is not accessible to the predator (e.g. rock crevices; Menge \& Lubchenco 1981).

Juvenile mussels are often highly susceptible to predation and their small, thin shells make them a preferred prey of many predators (Harger 1970, 1972, Elner 1978). For example, Landenberger (1968) showed that small $(<13 \mathrm{~mm})$ mussels were preferentially selected as prey in laboratory experiments by the predatory starfish Pisaster spp. Thus, Dare (1976) found $74 \%$ mortality in $25 \mathrm{~mm}$, and $98 \%$ mortality in $50 \mathrm{~mm}$ shell length mussels, and the classic work by Paine (1974) showed that removal of Pisaster ochraceus resulted in a downshore shift in the distribution of Mytilus californianus, along with an increase in the abundance of small mussels $(<13 \mathrm{~mm})$.

Intertidal predators of mussels can be pelagic, benthic, or terrestrial. During high tide, intertidal and subtidal predators include seastars (Paine 1969, 1974, Dolmer 1998), lobsters (Pollock 1979, Robles 1997, Robles et al. 2009), gastropods (Dye 1991, Gutiérrez \& Gallardo 1999), crabs (Menge et al. 1986, Caro et al. 2008), fish (Rilov \& Schiel 2006a), and octopuses (Boyle $\&$ Rodhouse 2005). During low tide, terrestrial species can gain access to mussel beds. These include birds (Siegfried 1977, Frank 1982, Kurle et al. 2008), mammals (Navarrete \& Castilla 1993, Stapp \& Polis 2003), and insects (Robles \& Cubit 1982), but generally only birds exert strong predation pressure (Goss-Custard 1980). Thus, predation is known to be a key biological effect controlling mussel populations in both northern (e.g. the starfish Pisaster ochraceus in California [Paine 1969] and birds on the Aleutian Islands [Kurle et al. 2008]) and southern (e.g. the gastropod Concholepas concholepas in Chile; Palmer 1984, Dye 1991) temperate regions.

All of these predators have different effects on mussel populations and their presence is strongly affected by the local habitat availability (e.g. adjacent subtidal reefs; Rilov \& Schiel 2006a,b) and hydrodynamics (Menge 1978). The effects of biological interactions such as predation are generally studied at rather small scales (Kurle et al. 2008), and, because interactions between predator and prey can differ in time and space, generalisation from small to large scales can create important errors in interpretation (Edwards et al. 1982). Recent studies have emphasised the variability that may exist within geographic regions. In New Zealand, Menge et al. (1999) found that the rates of grazing, predation, prey recruitment, and mussel growth were significantly different between the east and west coasts. They postulated that this was due to the different oceanographic conditions between the coasts, particularly the effects of upwelling. Their study mainly focused on benthic predators such as whelks and sea stars. The effects of more mobile fish and crab predators on the 2 coasts of New Zealand were examined by Rilov \& Schiel (2006a,b) who found that these varied with prey size and neighbouring habitats.

The situation appears to be quite different in South Africa, where predation can be a critical determinant of subtidal community structure, even driving the existence of alternative stable states (Penney \& Griffiths 1984, Barkai \& McQuaid 1988). In contrast, predation on intertidal mussels is believed to be a relatively minor cause of mussel mortality, compared to competition for space (Griffiths \& Hockey 1987), but studies of mussel predators there have focussed on adult mussels (e.g. Griffiths \& Seiderer 1980, C. L. Griffiths 1981, R. J. Griffiths 1981, McQuaid 1994).

There is a very strong biogeographic trend in mussel recruitment around the coast of South Africa (Harris et al. 1998), and along much of the coast mussel populations are believed to be recruitment-limited (McQuaid \& Phillips 2006, McQuaid \& Lindsay 2007, Bownes \& McQuaid 2009). In such situations it is likely that predation on earlier life stages may be critical to population regulation (G. Rilov et al. unpubl. data), even if predation on adults is limited. Here we examine predation of mussel recruits in South Africa under field conditions, distinguishing the effects of different types of predation (benthic or pelagic) by using manipulative experimentation. Because the study was conducted in a marine reserve where fishing is prohibited, we predicted that the effects of pelagic predators would be particularly strong and exceed those of benthic predators.

\section{MATERIALS AND METHODS}

Study site. Field work was conducted in Tsitsikamma National Park on the south coast of South Africa (34일 $01^{\prime} 18^{\prime \prime} \mathrm{S}, 23^{\circ} 53^{\prime} 44^{\prime \prime}$ E; Fig. 1). The shore is steeply shelving and moderately wave-exposed. The substratum consists of low-relief rock (shale) and partially 


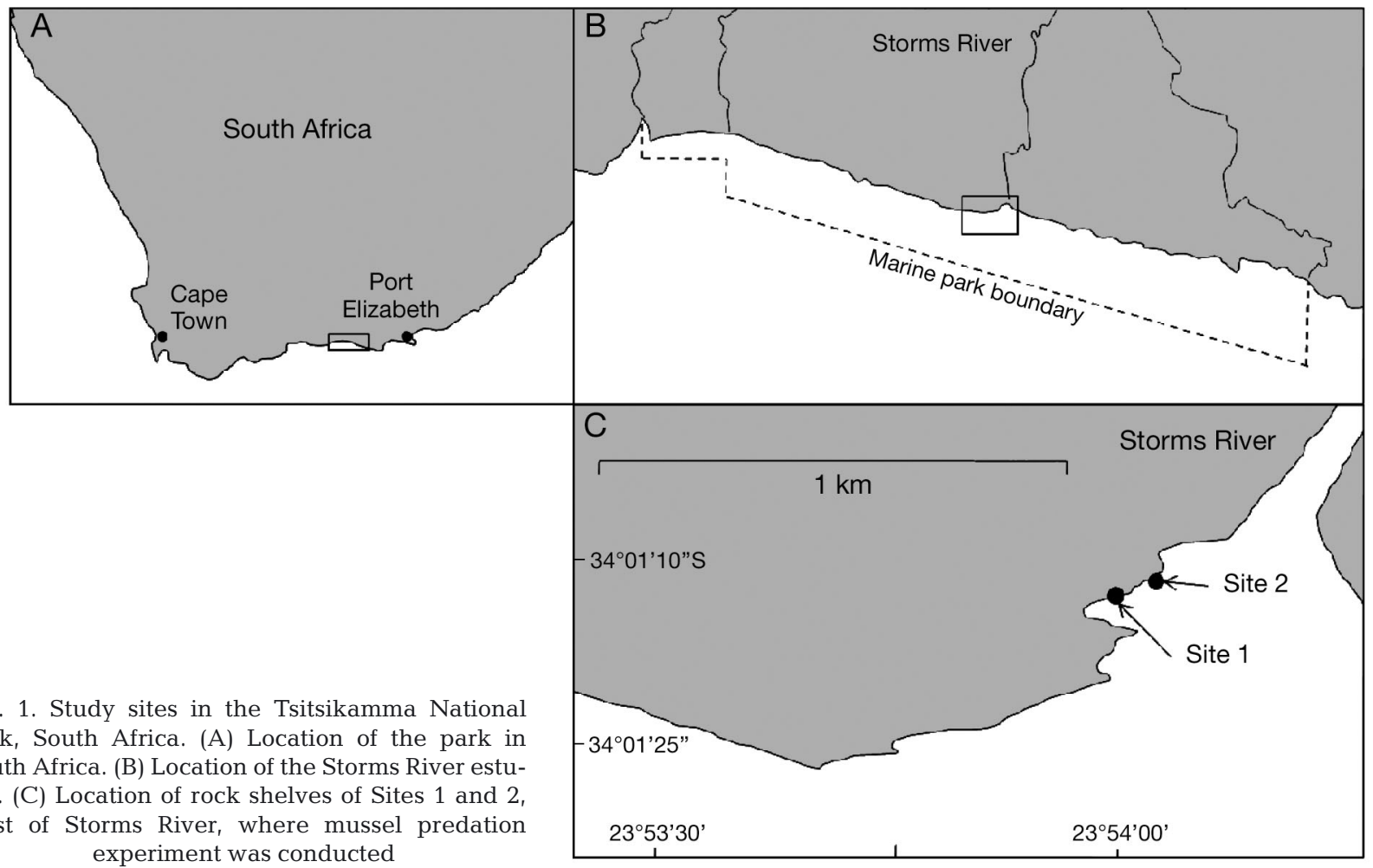

unconsolidated sediments with steep, rocky ridges extending from the shore line (Martin \& Flemming 1986).

The Tsitsikamma National Park, established in 1964, includes the oldest marine reserve in the country (extending $72 \mathrm{~km}$ alongshore and $5 \mathrm{~km}$ offshore; Fig. 1), within which no offshore or onshore fishing is permitted (Tinley et al. 1996). The 2 sites used (Site 1 and Site 2; Fig. 1) are relatively sheltered from wave action by a rocky headland approximately $600 \mathrm{~m}$ to the south.

Collection and mounting. Juvenile mussels (a mix of the invasive species Mytilus galloprovincialis and the indigenous Perna perna) were collected from Plettenberg Bay, $50 \mathrm{~km}$ west of the study site, during spring low tides in July 2009. Although this introduces the possibility of species-specific differences in vulnerability to predators, we believe that this is unlikely to have affected the results, as care was taken to ensure that species proportions were similar among treatments and sites. Mussels were transported to a field laboratory $3 \mathrm{~km}$ away in a bucket with seawater-dampened paper toweling to reduce desiccation.

Sorting and mounting of mussels occurred immediately after collection. Mussels of $\sim 2$ to $15 \mathrm{~mm}$ were used for the experiment and were kept in aerated seawater during sorting. Small and medium mussels were haphazardly selected, dried with paper toweling, and 25 individuals were attached in a circular pattern onto individual experimental tiles using Pratley's Steel Quickset epoxy as described by Lopez et al (2010). The tiles were $5 \times 5 \times 1 \mathrm{~cm}$ pieces of plastic that had been scoured on the application side and covered with a layer of epoxy approximately $2 \mathrm{~mm}$ thick. One valve of each mussel was applied to the epoxy leaving the other valve free to allow gaping, feeding, and secretion of byssal threads for natural attachment. Tiles with attached mussels were allowed to air dry and set for $30 \mathrm{~min}$, and then returned to aerated seawater. Tiles with mussels were attached to the shore using a screw through a pre-drilled hole in the centre during low tides on 20 July 2009 at Site 1 and the next day at Site 2.

Experimental design and treatments. To separate the effects of different types of predators, tiles with mussels were exposed to 3 types of caged treatments, replicated 5 times within each of the 2 sites. To permit only benthic predators, a roof treatment was used to exclude predators that would come from above such as birds and fish (Fig. 2C). To prevent benthic predation and allow only predation from above, a fence treatment was used (Fig. 2A). The third treatment was a full cage to eliminate all predation and to account for other causes of mortality (handling-induced mortality, detachment caused by wave action, desiccation, etc.; Fig. 2B). Procedural controls were used for each of the treatments to account for any artefacts of treatment. Procedural controls consisted of identical treatments 

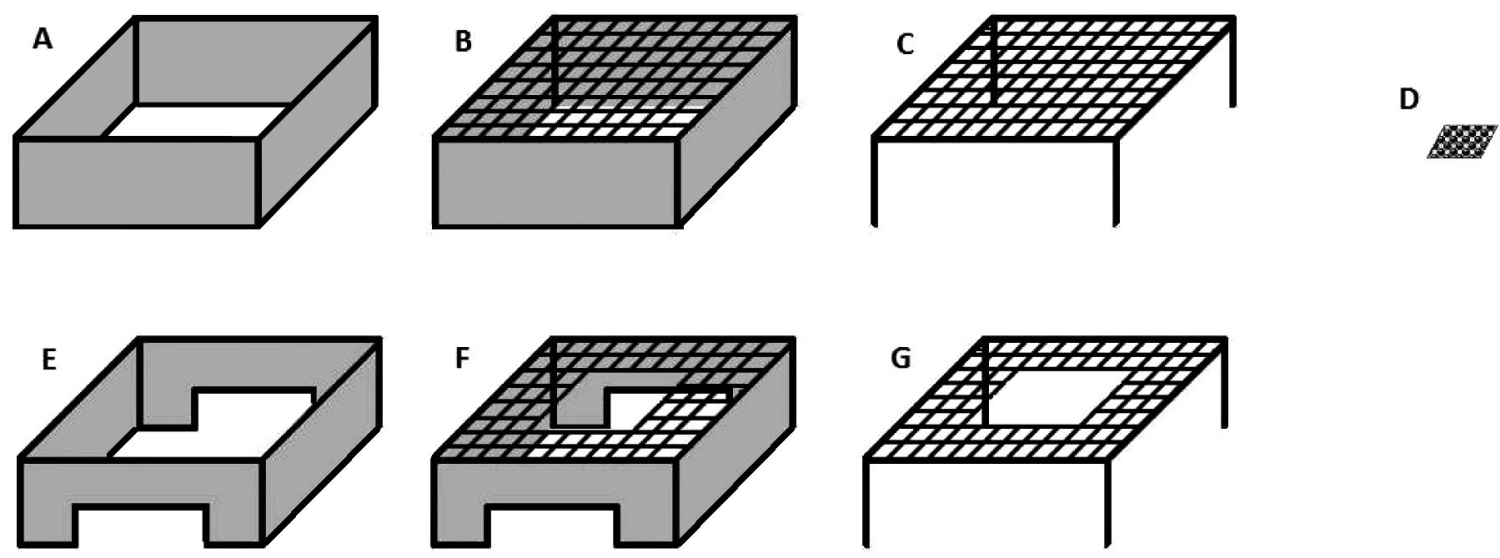

Fig. 2. Treatments used for the experimental exclusion of mussel predators. (A) Fence with no roof for exclusion of benthic predators. (B) Full cage for complete predator exclusion. (C) Roof for pelagic predator exclusion. (D) Control (unprotected tile). (E) Procedural control fence. (F) Procedural control full cage. (G) Procedural control roof. Tiles were screwed to the substratum in the centre of each treatment. Grey area indicates plastic side fencing

with large holes in the mesh of the sides or roof (Fig. 2E,F,G). Procedural controls were replicated 3 times within each site. Five control tiles were used at each site and were completely unprotected (Fig. 2D).

The cage frames were square $(15 \times 15 \mathrm{~cm}), 5 \mathrm{~cm}$ high, made of $6 \mathrm{~mm}$ steel rods. The sides were made of soft green plastic mesh with $0.25 \mathrm{~cm}^{2}$ mesh size. The side mesh was wrapped around the bottom of the frames bending towards the centre of the cage floor to prevent animals from crawling underneath. The roofs were made of steel, $1.2 \mathrm{~cm}^{2}$ mesh size. The procedural controls for fences had holes of $6 \times 3 \mathrm{~cm}$ centred on each of 2 sides, reaching the substratum. The roof of the procedural controls had holes $7 \times 7 \mathrm{~cm}$ in the centre. Roofs and fences were attached to frames with plastic cable ties.

The location of each cage, within the mussel zone where the 2 species of mussel co-exist, was scrubbed clean; cages and tiles were attached to the substratum using $60 \times 8 \mathrm{~mm}$ plastic anchors with a brass screw at each corner. Control sites were drilled with 4 holes with anchors and screws representing the corners of an absent cage. Treatments were allocated to plots haphazardly within the mussel beds.

Sampling. Because of limited mortality during tile preparation $(<5 \%)$, the living mussels on each tile were counted on deployment to standardise starting densities. Surviving mussels were then counted each day for $13 \mathrm{~d}$ during daytime low tides. Mussels were considered alive if still intact and attached to a tile. Individuals were counted as dead when (1) completely missing, (2) only one valve remained, or (3) gaping with no tissue between the valves.

Estimates of mussel and predator densities. Mussel cover and the abundance of whelks were estimated from 25 haphazard photographic quadrats of $861 \mathrm{~cm}^{2}$
$(33.5 \times 25.2 \mathrm{~cm})$ using a camera positioned $30 \mathrm{~cm}$ above the substratum with an aluminium rod. Fish abundances were estimated by snorkelling (using continuous, consistent fin kicks) along 100 m subtidal transects. Transects were conducted at both sites on $6 \mathrm{~d}$ during high tide. All pelagic fish and octopus within the range of visibility (generally 4 to $6 \mathrm{~m}$ ) were recorded (Thresher \& Gunn 1986). Visibility differed among days, but not between sites.

Intertidal line transects were used to determine the abundance of crabs at each site. Sampling was done 6 times, during night-time low tides, as crabs are generally more active during the night (Burrows et al. 1999). One $10 \mathrm{~m}$ transect was run perpendicular to the shore at each site. Crabs within $1 \mathrm{~m}$ to the right of the tape (measured using a $1 \mathrm{~m}$ aluminium rod) were counted, giving a sampling area of $10 \mathrm{~m}^{2}$.

Data analysis. Mussel survival data were converted to $\%$, as tiles had different starting numbers. Percentages were arcsine-square-root transformed to conform to the assumptions of normality and homogeneity (Zar 1999). A time-dependent sampling design can lend itself to a repeated measures ANOVA, but there may be problems of (1) increased chance of Type I error because of non-independence, (2) separation of variability in the error from variables, and (3) problems with interpretation when an interaction includes a time factor (Underwood 1997). Factorial ANOVAs were therefore used to assess the effects of site (2 levels) and treatment ( 7 levels) on survival of mussels, for each day separately. Both site and treatment were fixed, orthogonal factors. Homogeneity of variance was verified by Levene's test. A Fisher's least significant difference (LSD) post hoc test was used to identify which treatment caused statistical differences. 
Procedural controls (procedural fence, procedural roof, procedural full cage) were also tested against the control using a factorial ANOVA to check for artefacts of the cages. Adult mussel cover was arcsine-squareroot transformed and analysed using 1-way ANOVA, with site as a fixed factor. Fish and octopus abundances were analysed with Wilcoxon's paired signedranks non-parametric test to account for differences in visibility from day to day. Crab and whelk abundances were analysed using a Mann-Whitney nonparametric $U$-test. Where variances showed heteroscedasticity, the results were interpreted conservatively or not at all, depending on the alpha level. All statistical tests were completed with StatSoft Statistica 6.

\section{RESULTS}

\section{Mussel survival}

The main focus of the present study was to test the effect of the primary treatments (fence, roof, and full cage) in relation to the controls. Survival in the procedural controls never differed from that in the control (Table 1) indicating no caging artefacts and allowing to focus on treatment effects (Fig. 3).

At the end of $13 \mathrm{~d}$ there was $>85 \%$ survival of mussels at both sites in treatments that excluded all preda-

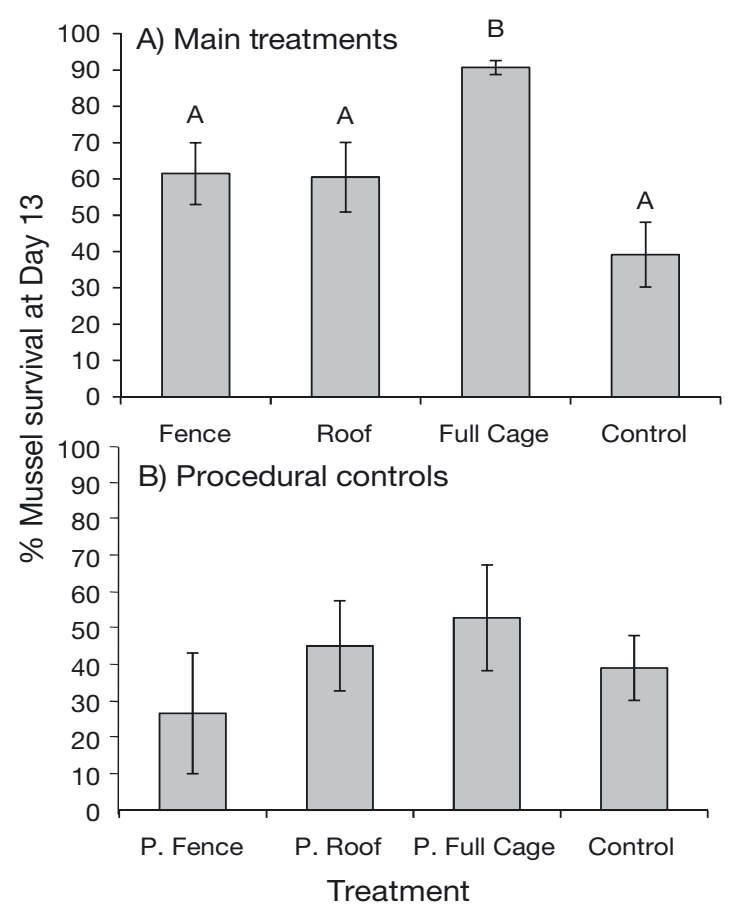

Fig. 3. Mussel survival (mean \pm SE across both sites, \%) at Day 13 with (A) main treatments (fence, roof, full cage) and control and (B) procedural controls (procedural fence, procedural roof, procedural full cage) and control. Letters in panel A indicate homogeneous subgroups (indicated by Fisher's least significant difference [LSD]; treatments carrying the same letter are not significantly different), there were no significant differences in panel B (see Tables 1 \& 2)
Table 1. Factorial 2-way ANOVA of procedural controls (fence, roof, full cage) and control at Site 1 and Site 2 on Days 2, 8, and 13. Data were arcsine-squareroot transformed. Significant $p$-values at $\alpha<0.05$ are indicated in bold

\begin{tabular}{|lccccc|}
\hline Effect & SS & df & MS & $F$ & $p$ \\
\hline Day 2 & & & & & \\
Site & 0.661 & 1 & 0.661 & 11.458 & $\mathbf{0 . 0 0 2}$ \\
Treatment & 0.405 & 3 & 0.135 & 2.337 & 0.104 \\
Site $\times$ Treatment & 0.105 & 3 & 0.035 & 0.606 & 0.619 \\
Error & 1.154 & 20 & 0.058 & & \\
Fishers's Site & & & & & $2<1$ \\
Levene's & & & & & $\mathbf{0 . 0 1 1}$ \\
Day 8 & & & & & \\
Site & 0.535 & 1 & 0.535 & 7.375 & 0.013 \\
Treatment & 0.209 & 3 & 0.070 & 0.961 & 0.430 \\
Site $\times$ Treatment & 0.170 & 3 & 0.057 & 0.784 & 0.517 \\
Error & 1.450 & 20 & 0.072 & & \\
Fishers's Site & & & & & $2<1$ \\
Levene's & & & & & 0.186 \\
Day 13 & & & & & \\
Site & & & 0.054 & 0.451 & 0.509 \\
Treatment & 0.054 & 1 & 0.084 & 0.708 & 0.560 \\
Site $\times$ Treatment & 0.252 & 3 & 0.029 & 0.246 & 0.863 \\
Error & 0.087 & 3 & & & 0.471 \\
Levene's & 2.370 & 20 & 0.119 & & \\
\hline
\end{tabular}

tors (full cage; Fig 3). Mussels that were exposed to all predators (control) had $<50 \%$ survival. The treatments that were exposed to partial predation (roof, fence) showed intermediate survival rates (roof and fence $>50 \%$ ), and constituted one homogeneous group with the control in the post hoc analysis (Fig. 3). ANOVA results show that by Day 1 , the effects of site, treatment, and the interaction between site and treatment were significant (Site: $F_{1,32}$ $=6.489, \mathrm{p}=0.015$; Treatment: $F_{3,32}=$ 9.839, $\mathrm{p}<0.001$; Site $\times$ Treatment: $F_{3,32}$ $=3.795, \mathrm{p}=0.019)$. Both the site and interaction effects ceased by Day 9 ( $p>0.20$ for both), while the treatment effect continued through the rest of the experiment (Table 2). After Day 7 , the results remained consistent. Mortality was consistently significantly lower in the full cage and equal in treatments with fences, roofs, or no protection (Fig. 4). 
Table 2. Mussel survival. ANOVA of main treatments and control on Sites 1 and 2 of Days 1 through 13. Data was arcsine-square-root transformed to reach normality. Significance is at $\alpha<0.05$ and is indicated in bold. Fishers's least significant difference (LSD) is given to identify homogenous groups for significant ANOVA effects. na: post hoc could not identify homogenous groups. FC: full cage; F: fence; R: roof; C: control. Levene's test for homogeneity is given for the interaction

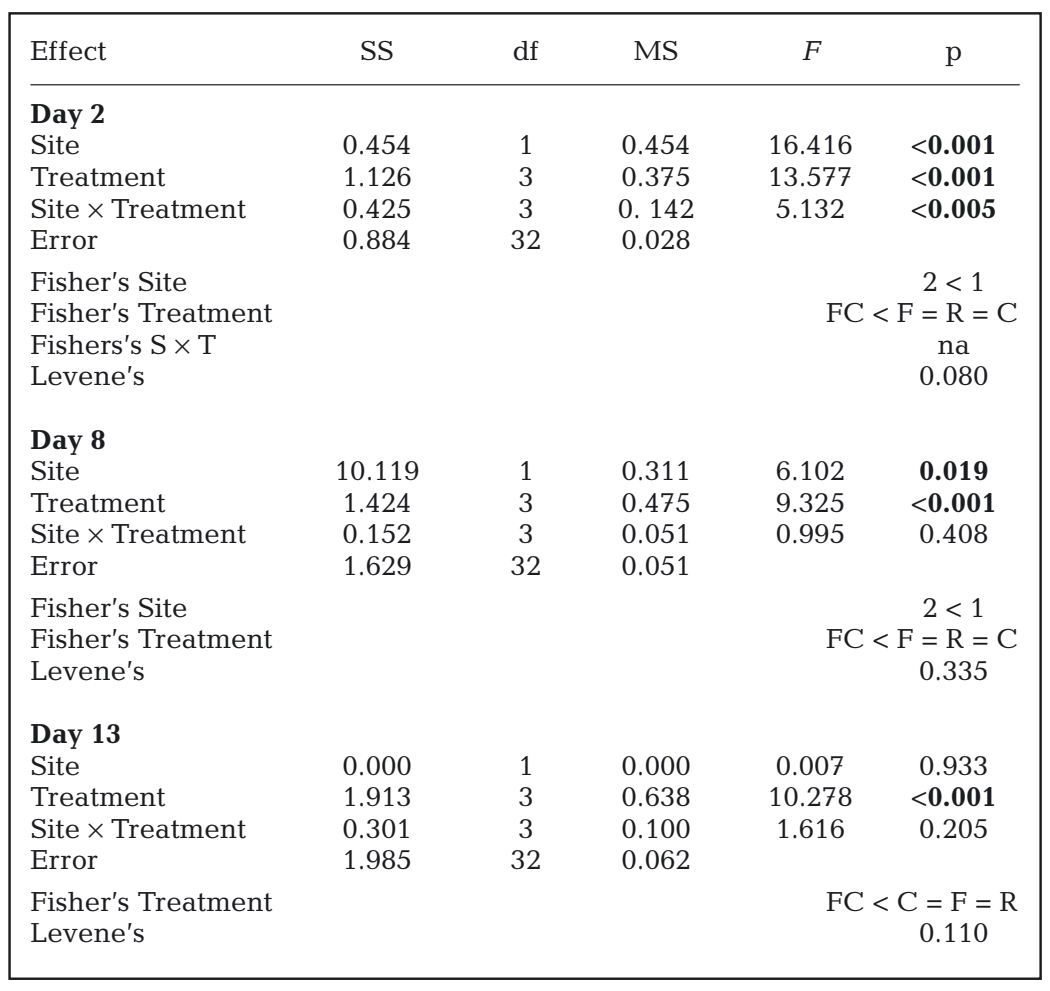

\section{Estimates of benthic and pelagic organisms}

Both sites were characterised by high levels of bare rock $(>30 \%)$. On average, mussel cover was around $20 \%$.

Whelks were highly visible and averaged about one per photograph $\left(861 \mathrm{~cm}^{2}\right)$ at both sites, with no significant differences in abundance between sites (MannWhitney $U$-test $=984.0, \mathrm{~N}_{1}=\mathrm{N}_{2}=50, \mathrm{p}=0.055$ ). Whelk species include the common dogwhelk Nucella dubia, ridged burnupena Burnupena cincta, and Burnupena lagenaria. No quantification was made of species due to the difficulty of identifying species from the photographs.

Crabs were active and abundant during the night ( 25 ind. $10 \mathrm{~m}^{-2}$; Fig. 5). Species present were the Cape rock crab Plagusia chabrus and Natal rock crab Grapsus grapsus tenuicrustatus. There was no difference in abundance between the sites (Mann-Whitney $U$-test $=23.5, \mathrm{~N}_{1}=\mathrm{N}_{2}=7, \mathrm{p}=0.898$ ).

Eight species of fishes were recorded at each site, and only one of these was a regular mussel feeder, the musselcracker Sparodon durbanensis (S. durbanesis was only present at Site 2, with one individual being seen on 3 different days). Blacktail Diplodus sargas capensis, strepie Sarpa salpa, and steentjie Spondyliosoma emarginatum were seen in large schools with $S$. salpa reaching schools of more than 300 individuals. The two-tone fingerfin Chirodactylus brachydactylus is not a schooling species, but it was regularly seen retreating to crevices. Janbruins Gymnocrotaphus curvidens, romans Chrysoblephus laticeps, and the puffer evileye blassop Amblyrhynchotes honckenii were also observed (Fig. 5). The octopus Octopus vulgaris was mostly seen at Site 2 and was the only species other than $C$. laticeps that differed significantly in numbers between the sites (Table 3). On 2 days the eagle ray Myliobatis aquila was seen in high numbers ( $\mathrm{n}=11$, Day 10; $\mathrm{n}=4$, Day 11), but was not present on any other occasions.

\section{DISCUSSION}

This was an experimental situation in which mussels would be expected to suffer unrealistically high levels of predation as they were offered to predators almost literally on a plate. Heavy settlement of mussel spat may result in such carpets of juvenile mussels (C. D. McQuaid pers. obs.), but normally they occur among adults where they are protected from predators and buffered against environmental extremes. Consequently, the levels of mortality recorded here are excessively high, even for caged mussels. The results indicate that mortality of exposed juvenile mussels through predation is rapid and high (ca. $50 \%$ in $13 \mathrm{~d}$ ). We tested the effects of different predator guilds (sensu Simberloff \& Dayan 1991), arbitrarily dividing them into benthic (excluded by fences) and pelagic (excluded by roofs) predators. Elsewhere, a particular guild of predators often dominates; for example the starfish Pisaster ochraceus in California, the whelk Concholepas concholepas in Chile, and fish in New Zealand. In contrast, we found that predation on juvenile mussels was well balanced between benthic and pelagic predators. This was unexpected as the experiments were undertaken in a marine reserve, where fish populations are protected against fishing and are particularly high for this coastline (Roberts \& Polunin 1991, Götz et al. 2008), so that higher rates of fish predation were anticipated. 


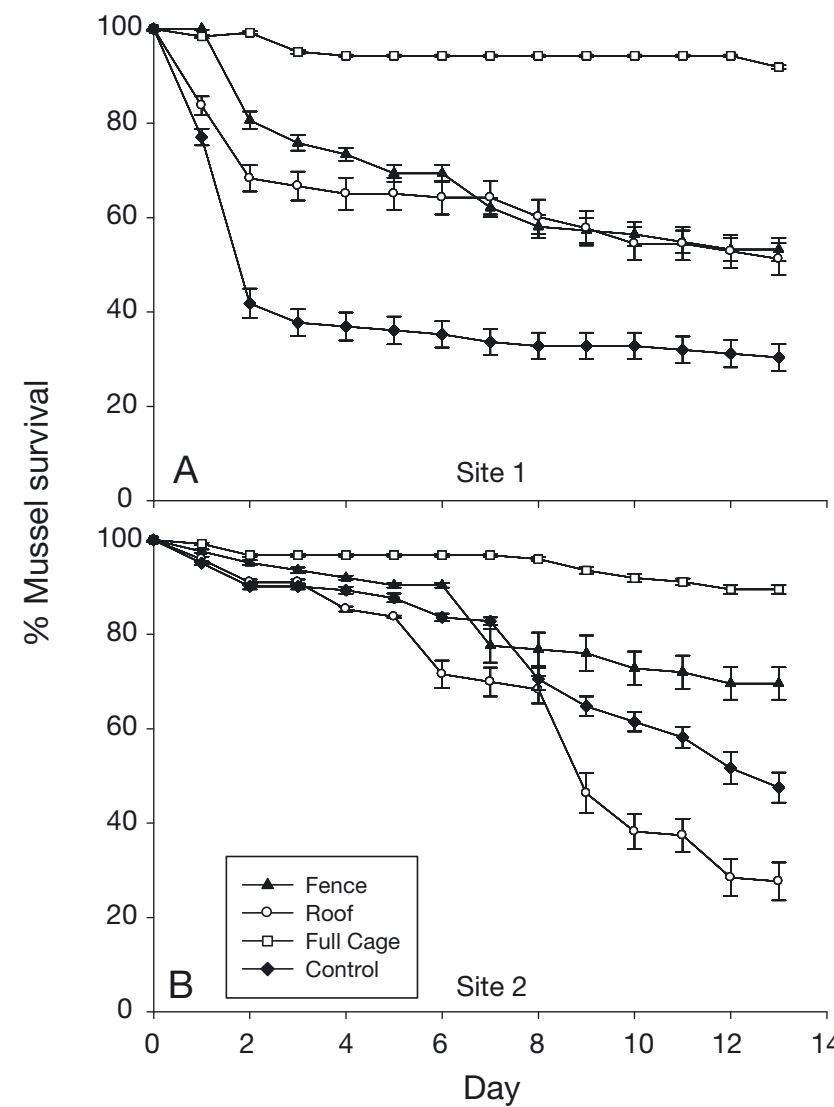

Fig. 4. Mussel survival experiment at 2 sites in Tsitsikamma National Park, South Africa, from July 20 to August 4, 2009. Survival (mean \pm SE) of mussels with full cage $(\square)$, roof $(O)$, fence $(\boldsymbol{\Delta})$, and control $(\diamond)$ treatments were tested to separate benthic and pelagic predation. (A) Site 1, (B) Site 2

Many of the primary mussel predators found in other parts of the world, or even other parts of the country, are not common or even present within the study area. For example, rock lobsters are voracious mussel predators in South Africa (Pollock 1979, Griffiths \& Seiderer 1980). The west-coast species Jasus lalandii does not extend this far east, while the east-coast rock lobster Panulirus homarus does not extend this far west (Berry 1974). A third species of lobster, $P$. gilchristi, is found in the study area, but only in deep waters (Branch et al. 1994). Likewise, predatory starfish, which are significant predators on the west coast (Penney \& Griffiths 1984), were not observed. Of the potential predators that were observed, crabs and whelks appear to be relatively unimportant. Two species of crabs (Plagusia chabrus and Grapsus grapsus tenuicrustatus) were common and occurred at relatively high abundances. Rilov \& Schiel (2006a) found $\sim 5$ crabs per pot laid out over night, while we recorded 25 per $10 \mathrm{~m}^{2}$ transect. Both our species are primarily herbivores but have mixed diets that can include sedentary animals (Griffin 1971, Branch et al. 1994, Edgar 2000). Intraspecific

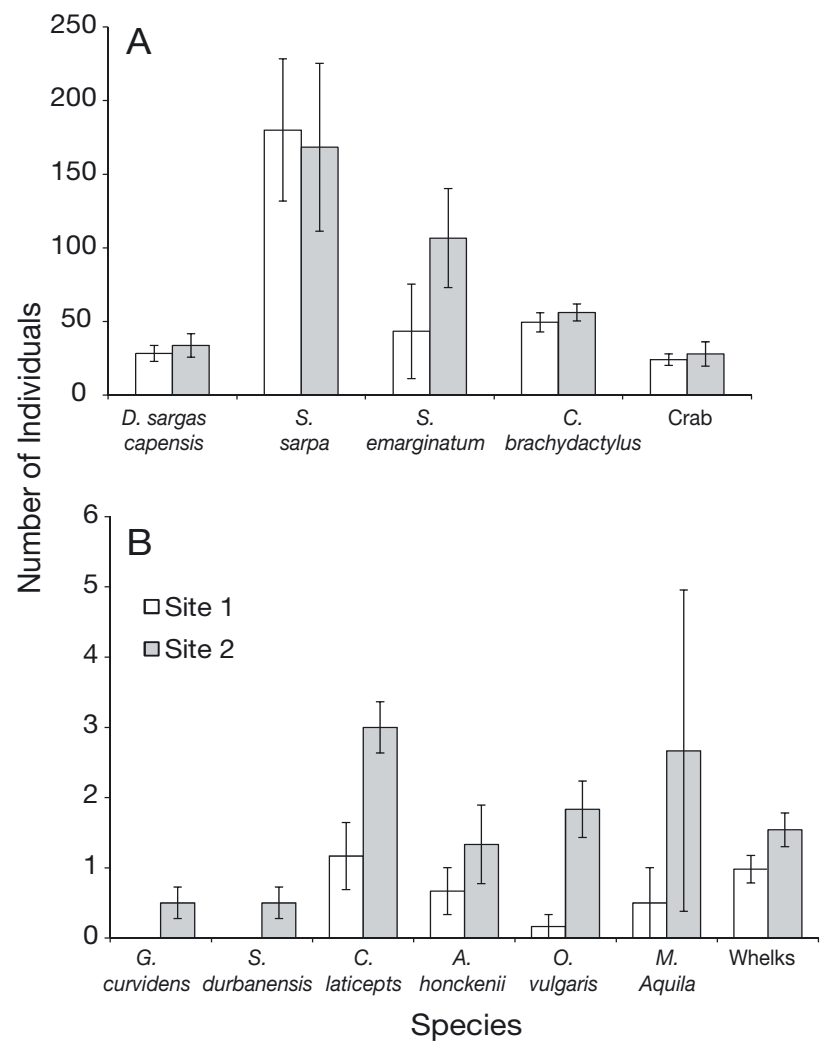

Fig. 5. Mean $( \pm \mathrm{SE})$ number of (A) high abundance blacktail Diplodus sargas capensis, strepie Sarpa salpa, steentjie Spondyliosoma emarginatum, twotone fingerfin Chirodactylus brachydactylus, crab Grapsus grapsus tenuicrustatus and Plagusia chabrus, and (B) low abundance janbruins Gymnocrotaphus curvidens, musselcracker Sparodon durbanensis, roman Chrysoblephus laticeps, evileye blassop Amblyrhynchotes honckenii, octopus Octopus vulgaris, eagle ray Myliobatis aquila, and whelks Nucella dubia, Burnupena cincta, and Burnupena lagenaria. Values for fish and octopus: number of individuals per $15 \mathrm{~m}$ swim over 6 different days; for crab: number of individuals per $10 \mathrm{~m}^{2}$ over 6 days; for whelks: number of individuals per $861 \mathrm{~cm}^{2}$

Table 3. Wilcoxon signed-ranks test on individual fish species data collected at 2 sites over $6(n=6) d$. Data were collected on Days 1, 4, 10, 11, 12, and 13 during the daytime high tide. Significant differences $(p<0.05)$ in abundance between the 2 sites are indicated in bold. T: test-statistic for the Wilcoxon signed-ranks test; $\mathrm{Z}$ : standard values of the normal distribution

\begin{tabular}{|lccc|}
\hline Species & $\mathrm{T}$ & $\mathrm{Z}$ & $\mathrm{p}$ \\
\hline Diplodus sargas capensis & 6.00 & 0.943 & 0.345 \\
Sarpa salpa & 9.00 & 0.313 & 0.753 \\
Spondyliosoma emarginatum & 3.50 & 1.468 & 0.142 \\
Gymnocrotaphus curvidens & 0.00 & 1.604 & 0.109 \\
Sparodon durbanensis & 0.00 & 1.604 & 0.109 \\
Chrysoblephus laticeps & 0.00 & 2.023 & $\mathbf{0 . 0 4 3}$ \\
Chirodactylus brachydactylus & 4.00 & 1.363 & 0.173 \\
Amblyrhynchotes honckenii & 1.50 & 1.278 & 0.201 \\
Octopus vulgaris & 0.00 & 2.201 & $\mathbf{0 . 0 2 8}$ \\
\hline
\end{tabular}


competition at high densities could lead to feeding on juvenile mussels (Smallegange et al. 2006), but this seems unlikely. Whelks are important mussel predators on the west coast of South Africa (Wickens \& Griffiths 1985), and Nucella spp. are a mussel predator both in Europe (Hughes \& Dunkin 1984) and in South Africa (Wickens \& Griffiths 1985). Some Burnupena spp. are predators of barnacles, mussels, and Littorina spp. (McQuaid 1982, 1985, Barkai \& McQuaid 1988), but the species found in the present study are believed to be scavengers (Branch et al. 1994). The manner in which mussels were removed often entailed the loss of all individuals within a treatment from one day to the next, while mussel predation by whelks would be slow, with gradual removal of prey. Furthermore, though whelk feeding normally continues during emersion (McQuaid 1985, Burrows \& Hughes 1989), whelk predation was never observed during sampling at low tide.

Of the mobile, subtidal species identified during snorkelling, only 2 are known mussel predators, the musselcracker Sparodon durbanensis and Octopus vulgaris. Rilov \& Schiel $(2006 a, b)$ found that the effect of fish predation on mussels was significantly higher at sites with a subtidal reef close to the mussel bed than at sites where the adjacent substratum was sandy. Both our sites extended from intertidal rock platforms into the subtidal, offering high structural complexity and suitable habitat for both fish and octopus (Smale \& Buchan 1981, Buxton \& Clarke 1991). Buxton \& Clarke (1991) did not find molluscs to be the main constituent of musselcracker diet, but the frequency of mussels within guts was high at all fish life stages, with an increase in prey size during later life stages. This suggests that mussels used in the present study might have been taken by younger fish. $O$. vulgaris is an important mussel predator on the coast of South Africa (Buchan \& Smale 1981, Griffiths \& Hockey 1987). A limitation of our study is that the roof treatment may have been ineffective against octopuses. Octopuses can forage by entering crevices only slightly bigger than their beak (Mather 1991), so that small individuals may have been able to fit or reach below the roofs. Smale \& Buchan (1981) found that Perna perna was the main constituent of the diet of $O$. vulgaris, with mussels making up to $73 \%$ of the diet of octopuses and octopus densities of 1 per $12 \times 12 \mathrm{~m}$ quadrat. Relatively few octopuses were seen during 15 min swims in the present study, but our counts may have been underestimates given the cryptic behaviour of octopuses. Furthermore, remnants of cracked and drilled mussel shells were common (J. G. Plass-Johnson pers. obs.) indicating the possible 'drilling' technique seen with octopuses (McQuaid 1994), or the 'cracking' technique of the Sparidae family (Fernandez \& Motta 1997). The primary predators here seem to have been subtidal, highly mobile, and capable of removing many mussel recruits in a single session. Both octopus and musselcracker could produce the patterns seen here.

The present study explored the effects of different guilds of predators on mussels in a context of potentially high abundances of predators (i.e. within a marine protected area); but while a single species of predator can be critical in other parts of the world, our results indicate the importance of a combined effect of multiple types of predation. Experimental designs and analysis should consider the interactive effects of different predators (Soluk \& Collins 1988), as predators will rarely have the additive or linear effects on prey that are often tested (i.e. proportion of mortality from predator $\mathrm{A}+$ proportion of mortality from predator $\mathrm{B}=$ full mortality). The interaction of predators can limit or facilitate effects on prey causing non-linear relationships (Billick \& Case 1994). Sih et al. (1998) explored the complications of studies with multiple predator effects. Interactions (either inter- or intra-specific) among predators can be affected by both predator and prey densities and by their behaviour. Multiple predators can have risk-enhancing or risk-reducing behaviours that cause higher or lower predation on the prey, and this cannot be predicted based on knowledge of each predator separately. Often multiple predator species are able to interfere with each other, resulting in risk reduction for a shared prey species (Peckarsky 1991, Griffen \& Byers 2006). In contrast, higher prey densities can reduce predator interactions, changing per capita predation (Abrams \& Ginzburg 2000). Predator interactions can also change on different time scales. For example, some predators, such as whelks and octopus, can continue foraging during emersion, at least at night (J. G. Plass-Johnson pers. obs.), while others, such as fish, are constrained by the tide. On a different time scale of days, the quality of the experimental plots as feeding patches would have declined as the number of mussels on the plates was reduced and this is likely to affect predator behaviour and interactions. This may also explain why the expected effects of large fish populations did not occur, though this would need to be tested through direct experimentation.

Due to the restrictions intrinsic to our sampling method, elucidation of the exact predators is not possible, although this does provide a starting point for studies that target organisms feeding specifically on juvenile mussels. Also, it is impossible to extrapolate from the rates of predator-driven mortality observed here to natural rates; but the fact that we found juvenile mussels surviving for over $13 \mathrm{~d}$ while completely exposed to predators suggests that natural rates will be low compared to other parts of the world, not only trop- 
ical systems (e.g. Menge \& Lubchenco 1981), but also in other temperate areas (e.g. Marsh 1986, whose measurements of bird predation included effects on mussel recruits, and Menge et al. 2002, who measured predation on adult mussels (Lopez et al 2010). This accords with the findings for adult mussels in South Africa (Griffiths \& Hockey 1987) and adds to the idea that mussel populations are not controlled from the top down by predation, though its effect can be important (the present study and Rilov et al. unpubl. data). This contrasts with other parts of the world and has implications for population regulation in this important habitat engineer. Even weak biological interactions can have powerful effects on community structure (Berlow 1999). Nevertheless, given the high levels of biological diversity and endemism of marine communities in South Africa (Roberts et al. 2002), their age compared to the younger intertidal communities of the north Atlantic, where predation can have a major effect on the utilisation of space (e.g. Menge 1976) and the enormous predation pressure that can be exerted in adjacent subtidal systems in South Africa (Barkai \& McQuaid 1988, Barkai et al. 1996), it is surprising that guilds of intertidal predators have not evolved that are capable of exerting stronger top-down influence.

Acknowledgements. Special thanks go to the many field assistants for their painstaking help in preparation and on the shore. We thank SANPARKS and the park rangers of Tsitsikamma National Park for the much valued advice and help. Thanks to M. Villet for assistance with statistical analysis and to the 3 anonymous reviewers for their suggestions. This work is based upon research supported by the South African Research Chairs Initiative of the Department of Science and Technology and National Research Foundation.

\section{LITERATURE CITED}

Abrams PA, Ginzburg LR (2000) The nature of the problem: prey dependent, ratio dependent or neither? Trends Ecol Evol 15:337-341

Barkai A, McQuaid DC (1988) Predator-prey role reversal in a marine benthic ecosystem. Science 242:62-64

Barkai A, Davis CL, Tugwell S (1996) Prey selection by the South African Cape rock lobster Jasus Lalandii: ecological and physiological approaches. Bull Mar Sci 58:1-8

Berlow EL (1999) Strong effects of weak interactions in ecological communities. Nature 398:330-334

Berry PF (1974) A revision of the Panulirus homarus-group of spiny lobster (Decapoda, Palinuridae). Crust Int J Crust Res 27:31-42

Billick I, Case TJ (1994) Higher order interactions in ecological communities: what are they and how can they be detected? Ecology 75:1529-1543

Bownes SJ, McQuaid CD (2009) Mechanisms of habitat segregation between an invasive and an indigenous mussel: settlement, post-settlement mortality and recruitment. Mar Biol 156:991-1006

Boyle PR, Rodhouse FP (2005) Cephalopods: ecology and fisheries. Blackwell Publishing, Oxford
Branch GM, Griffiths CL, Branch ML, Bechley LE (1994) Two oceans: a guide to the marine life of southern Africa. David Philip Publishers, Claremont

Bruno JF, Stachowicz JJ, Bertness MD (2003) Inclusion of facilitation into ecological theory. Trends Ecol Evol 18: 119-125

Buchan PR, Smale MJ (1981) Estimates of biomass, consumption and production of Octopus vulgaris Cuvier off the east coast of South Africa. Oceanogr Res Inst Durban Investig Rep 50:1-9

Burrows MT, Hughes RN (1989) Natural foraging of the dogwhelk, Nucella lapillus (Linnaeus); the weather and whether to feed. J Molluscan Stud 55:285-295

> Burrows MT, Kawai K, Hughes RN (1999) Foraging by mobile predators on a rocky shore: underwater TV observations of movements of blennies Lipophrys pholis and crabs Carcinus maenas. Mar Ecol Prog Ser 187:237-250

Buxton CD, Clarke JR (1991) The biology of the white musselcracker Sparodon durbanensis (Pisces: Sparidae) on the eastern Cape coast, South Africa. S Afr J Mar Sci 10: 285-296

Caro AU, Escobar J, Bozinovic F, Navarrete SA, Castilla JC (2008) Phenotypic variability in byssus thread production of intertidal mussels induced by predators with different feeding strategies. Mar Ecol Prog Ser 372:127-134

Connell JH (1972) Community interactions on marine rocky intertidal shores. Annu Rev Ecol Syst 3:169-192

Dare PJ (1976) Settlement, growth and production of the mussel Mytilus edulis L., in Morecambe Bay, England. Fish Invest GB II 28:1-25

> Dolmer P (1998) The interaction between bed structure of Mytilus edulis L. and the predator Asterias rubens L. J Exp Mar Biol Ecol 228:137-150

> Dye AH (1991) Feed preference of Nucella crassilabrum and juvenile Concholepas concholepas (Gastropoda: Muricidae) from a rocky shore in southern Chile. J Mollusc Stud 57:301-307

Edgar GJ (2000) Australian marine life: the plants and the animals of temperate waters, 2nd ed. Reed Books, Melbourne

Edwards DC, Conover DO, Sutter F (1982) Mobile predators and the structure of marine intertidal communities. Ecology $63: 1175-1180$

- Elner RF (1978) The mechanics of predation by the shore crabs, Carcinus maenus on the edible mussel, Mytilus edulis. Oecologia 36:333-344

Fernandez LP, Motta PJ (1997) Trophic consequences of differential performance: ontogeny of oral jaw-crushing performance in the sheepshead, Archosargus probatocephalus (Teleostei, Sparidae). J Zool (Lond) 243: 737-756

Frank PW (1982) Effects of winter feeding on limpets by black oystercatchers, Haematopus bachmani. Ecology 63: 1352-1362

Gosling EM (1992) Systematics and geographic distribution of Mytilus. Dev Aquacult Fish Sci 25:1-20

Goss-Custard JD (1980) Competition for food and interference among waders. Ardea 69:31-52

Götz A, Cowley PD, Winker H (2008) Selected fishery and population parameters of eight shore-angling species in the Tsitsikamma National Park no-take marine reserve. S Afr J Mar Sci 30:519-532

Griffen BD, Byers JE (2006) Partitioning mechanisms of predator interference in different habitats. Oecologia 146: 608-614

Griffin DJG (1971) The ecological distribution of grapsid and ocypodid shore crabs in Tasmania. J Anim Ecol 40: $597-621$ 
Griffiths CL (1981) Predation on the bivalve Choromytilus meridionalis ( $\mathrm{Kr}$.) by the gastropod Natica (Tectonatica) tecta Anton. J Molluscan Stud 47:112-120

Griffiths CL, Hockey PAR (1987) A model describing the interactive roles of predation, competition and tidal elevation in structuring mussel populations. S Afr J Mar Sci 5:547-556

Griffiths CL, Seiderer LJ (1980) Rock-lobsters and mussels limitation and preferences in a predator-prey interaction. J Exp Mar Biol Ecol 44:95-109

Griffiths RJ (1981) Population dynamics and growth of the bivalve Chromomytilus meridionalis (Kr.) at different tidal levels. Estuar Coast Shelf Sci 12:101-118

- Gutiérrez RM, Gallardo CS (1999) Prey attack, food preference and growth in juveniles of the edible muricid snail, Chorus giganteus. Aquaculture 174:69-79

Harger JRE (1970) The effect of wave impact on some aspects of the biology of sea mussels. Veliger 12:401-414

Harger JRE (1972) Competitive coexistence among intertidal invertebrates. Am Sci 60:600-607

Harris JM, Branch GM, Elliott BL, Currie B and others (1998) Spatial and temporal variability in recruitment of intertidal mussels around the coast of southern Africa. S Afr J Zool 33:1-11

$>$ Holt RD (1977) Predation, apparent competition and the structure of prey communities. Theor Popul Biol 12: 197-229

Hughes RN, Dunkin SDB (1984) Behavioural components of prey selection by dogwhelks, Nucella lapillus (L.) feeding on mussels, Mytilus edulis L., in the laboratory. J Exp Mar Biol Ecol 77:45-68

Kitching JA, Sloane JF, Ebling FJ (1959) The ecology of the Lough Ine: mussels and their predators. J Anim Ecol 28: 331-341

Kurle CM, Croll DA, Tershy BR (2008) Introduced rats indirectly change marine rocky intertidal communities from algae- to invertebrate-dominated. Proc Natl Acad Sci USA 105:3800-3804

Landenberger DE (1968) Studies on selective feeding in the Pacific starfish Pisaster in southern California. Ecology 49:1062-1075

Lopez MS, Coutinho R, Ferreira CEL, Rilov G (2010) Predator-prey interactions in a bioinvasion scenario: differential predation by native predators on two exotic rocky intertidal bivalves. Mar Ecol Prog Ser 403:101-112

- Marsh CP (1986) Rocky intertidal community organization: the impact of avian predators on mussel recruitment. Ecology 67:771-786

Martin AK, Flemming BW (1986) The Holocene shelf sediment wedge off the south and east coast of south Africa. In: Knight JR, McLean JR (eds) Shelf sands and sandstones. Canadian Society of Petroleum Geologists, Memoir $2: 27-44$

Mather JA (1991) Foraging, feeding and prey remains in middens of juvenile Octopus vulgaris (Mollusca: Cephalopoda). J Zool (Lond) 224:27-39

> McQuaid CD (1982) The influence of desiccation and predation on vertical size gradient in a population of the gastropod Oxystele variegate (Anton) on an exposed rocky shore. Oecologia 53:123-127

McQuaid CD (1985) Differential effects of predation by the intertidal whelk Nucella dubia (Kr.) on Littorina africana knysnaensis (Phillipi) and the barnacle Tetraclita serrata Darwin. J Exp Mar Biol Ecol 89:97-107

McQuaid CD (1994) Feeding behaviour and selection of bivalve prey by Octopus vulgaris Cuvier. J Exp Mar Biol Ecol 177:187-202
McQuaid CD, Branch GM (1984) Influence of sea temperature, substratum and wave exposure on rocky intertidal communities: an analysis of faunal and floral biomass. Mar Ecol Prog Ser 19:145-151

> McQuaid CD, Lindsay TL (2007) Wave exposure effects on population structure and recruitment in the mussel Perna perna suggest regulation primarily through availability of recruits and food, not space. Mar Biol 151:2123-2131

McQuaid CD, Phillips TE (2006) Mesoscale variation in reproduction, recruitment and population structure of intertidal mussels with low larval input: a bay/open coast comparison. Mar Ecol Prog Ser 327:193-206

> Menge BA (1976) Organization of the New England rocky intertidal community: role of predation, competition, and environmental heterogeneity. Ecol Monogr 46:355-393

> Menge BA (1978) Predation intensity in a rocky intertidal community: effect of algal canopy, wave action and desiccation on a predator feeding rate. Oecologia 34:17-35

Menge BA, Lubchenco J (1981) Community organization in temperate and tropical rocky intertidal habitats: prey refuge in relation to consumer pressure gradients. Ecol Monogr 51:429-450

> Menge BA, Lubchenco J, Ashkenas LR, Ramsey F (1986) Experimental separation of effects of consumers on sessile prey in the low zone of a rocky shore in the Bay of Panama: direct and indirect consequences of food web complexity. J Exp Mar Biol Ecol 100:225-269

Menge BA, Daley BA, Lubchenco J, Sanford E and others (1999) Top-down and bottom-up regulation of New Zealand rocky intertidal communities. Ecol Monogr 69: 297-330

> Menge BA, Sanford E, Daley BA, Tess L (2002) Inter-hemispheric comparison of bottom-up effects on community structure: insights revealed using the comparative-experimental approach. Ecol Res 17:1-16

Muntz L, Ebling FJ, Kitching JA (1965) Predatory activity of large crabs. J Anim Ecol 34:315-329

> Navarrete SA, Castilla JC (1993) Predation by Norway rats in the intertidal zone of central Chile. Mar Ecol Prog Ser 92: 187-199

Paine RT (1969) The Pisaster-Tegula interaction: prey patches, predator food preference, and intertidal community structure. Ecology 50:950-961

> Paine RT (1974) Intertidal community structure: experimental studies on the relationship between a dominant competitor and its principal predator. Oecologia 15:93-120

Paine RT (1977) Controlled manipulations in the marine intertidal zone, and their contributions to ecological theory. Acad Nat Sci Spec Pub 12:245-270

Palmer AR (1984) Prey selection by thaidid gastropods: some observational and experimental field tests of foraging models. Oecologia 62:162-172

> Peckarsky BL (1991) Mechanisms of intra- and interspecific interference between larval stoneflies. Oecologia 85: $521-529$

> Penney AJ, Griffiths CL (1984) Prey selection and the impact of the starfish Marthasterias glacialis (L.) and other predators on the mussel Choromytilus meridionalis (Krauss). J Exp Mar Biol Ecol 75:19-36

Petraitis PS, Latham RE, Niesenbaum RA (1989) The maintenance of species diversity by disturbance. Q Rev Biol 64: 393-418

Pollock DE (1979) Predator-prey relationship between the rock lobster Jasus lalandii and the mussel Aulacomya ater at Robben Island on the Cape west coast of Africa. Mar Biol 65:1-12

Power ME (1992) Top-down and bottom-up forces in food webs: do plants have primacy? Ecology 73:733-746 
Rilov G, Crooks JA (2009) Biological invasions in marine systems: ecological management and geographical perspectives. Springer, Heidelberg

Rilov G, Schiel DR (2006a) Trophic linkages across seascapes: subtidal predators limit effective mussel recruitment in rocky intertidal communities. Mar Ecol Prog Ser 327: 83-93

Rilov G, Schiel DR (2006b) Seascape-dependent subtidalintertidal trophic linkages. Ecology 87:731-744

Roberts CM, Polunin NVC (1991) Are marine reserves effective in the management of reef fishes? Rev Fish Biol Fish 1:65-91

Roberts CM, McClean CJ, Veron JEN, Hawkins JP and others (2002) Marine biodiversity hotspots and conservation priorities for tropical reefs. Science 295:1280-1284

Robles CD (1997) Changing recruitment in constant species assemblages: implications for predation theory in intertidal communities. Ecology 78:1400-1414

Robles C, Cubit JD (1982) Influence of biotic factors in an upper intertidal community: effects of Diptera and algae on rocky shores. Oecologia 54:23-31

Robles CD, Desharnais R (2002) History and current development of a paradigm of predation in rocky intertidal communities. Ecology 83:1521-1536

Robles CD, Desharnais R, Garza C, Donahue MJ, Martinez CA (2009) Complex equilibria in the maintenance of boundaries: experiments with mussel beds. Ecology 90: 985-995

Ruiz GM, Carlton JT, Grosholz ED, Hines AH (1997) Global invasions of marine and estuarine habitats by non-indigenous species: mechanisms, extent and consequences. Am Zool 37:621-632

Saier B (2001) Direct and indirect effects of seastars Asterias rubens on mussel beds (Mytilus edulis) in the Wadden Sea. J Sea Res 46:29-42

Editorial responsibility: Roger Hughes,

Bangor, UK
Siegfried WR (1977) Mussel-dropping behaviour of kelp gulls. S Afr J Sci 73:337-341

Sih A, Englund G, Wooster D (1998) Emergent impacts of multiple predators on prey. Trends Ecol Evol 13:350-355

Simberloff D, Dayan T (1991) The guild concept and the structure of ecological communities. Annu Rev Ecol Syst 22: 115-143

Smale MJ, Buchan PR (1981) Biology of Octopus vulgaris off the east coast of South Africa. Mar Biol 65:1-12

Smallegange IM, van der Meer J, Kurvers RHJM (2006) Disentangling interference competition from exploitative competition in a crab-bivalve system using a novel experimental approach. Oikos 113:157-167

Soluk DA, Collins NC (1988) Synergistic interactions between fish and stoneflies: facilitation and interference among stream predators. Oikos 52:94-100

Stokstad E (2009) On the origin of ecological structure. Science 326:33-35

Stapp P, Polis GA (2003) Marine resources subsidize insular rodent populations in the Gulf of California, Mexico. Oecologia 134:496-504

Thresher RE, Gunn JS (1986) Comparative analysis of visual census techniques for highly mobile, reef associated piscivores (Carangidae). Environ Biol Fishes 17:93-116

Tinley RL, Nelson G, Radloff SE, Buxton CD (1996) Ichthyoplankton distribution and dispersal in the Tsitsikamma National Park marine reserve, South Africa. S Afr J Mar Sci 17:1-14

Underwood AJ (1997) Experiments in ecology. Cambridge University Press, Cambridge

Wickens PA, Griffiths CL (1985) Predation by Nucella cingulata (Linnaeus, 1771) on mussels, particularly Aulacomya ater (Molina, 1782). Veliger 27:366-374

Zar JH (1999) Biostatistical analysis, 4th ed. Prentice-Hall, Upper Saddle River, NJ

Submitted: March 12, 2010; Accepted: June 1, 2010

Proofs received from author(s): July 23, 2010 